\title{
Actual Issues of Female Reproductive Health in Ukraine
}

\author{
Viacheslav V Kaminsky* \\ Department of Obstetrics and Gynaecology, NAMS of Ukraine, Ukraine
}

Submission: April 27, 2018; Published: May 31, 2018

*Corresponding author: Viacheslav V Kaminsky, Department of Obstetrics and Gynaecology, NAMS of Ukraine, Ukraine; Email: kagir@ukr.net

Keywords: Reproductive health; Age structure; Demographic policy; Reproductive potential; Emerging generation; International standards; Low fertility rate; Stillbirth; Ukraine; Spontaneous abortion; Congenital malformations; Infant mortality; Perinatal; Natural fertility; Ukrainian families; Infertility; Clinical pregnancy; Medical-organizational; Maternal; Fertile age; Female and male infertility

\section{Background}

In the conditions of the projected further decline in the population of Ukraine, the strengthening of the negative dynamics of its age structure and the growth of the economic burden on the able-bodied population, the most important problem of demographic policy and the necessary condition for ensuring national security of the country is to increase the reproductive potential and preserve the health of the emerging generation. In this case, the state of reproductive health, which is an integral part of the health of the nation as a whole and of strategic importance for the sustainable development of society, causes particular concern. At present, the state of reproductive health of the nation is far beyond the international standards and is characterized by a low fertility rate against the background of a high level of the main constituents of the threat of reproduction of the person-infertility, stillbirth, spontaneous abortion, congenital malformations, maternal, perinatal and infant mortality [1].

\section{Discussion}

One of the reasons for reducing the reproductive potential of the population is the decline in natural fertility, which is due to an increase in the proportion of infertility. One of the integral indicators of reproductive health is infertility. According to official statistics, in 2016, the infertility rate in Ukraine is low - $3.8 \%$ per 1,000 women of fertile age and $0.90 \%$ male. At the same time, sociological studies show that $6.8 \%$ of Ukrainian families, that is, about 1 million married couples, are affected by unwanted infertility. Infertile marriage is an important medical and social problem that requires at each stage of development of society and health care to clarify the medical-organizational forms of medical care. The incompleteness of the registration of female and male infertility suggests a significant range of fluctuations in its prevalence in the regions - from $19.74 \%$ in Zaporozhye to $1.69 \%$ in the Rivne regions, and in men from $14.11 \%$ in Zaporozhye to $0.03 \%$ in Kharkiv oblasts [2]. The results show that although nurses and doctors regard EHI as important for patients, more education, support and resources will increase their ability to do so effectively. On the basis of the received data, ideas and recommendations for continuing education in this area were presented [3].

\section{Conclusion}

The multifactorial nature of the process of reducing reproductive health in Ukraine determines the need to improve new methods of treatment of infertility. The positive tendencies of changes in reproductive behavior of the population (increase in fertility) and increase of the efficiency of the population reproduction process (increase in the frequency of onset of clinical pregnancy), which are planned during the last years, characterize the correctness of the chosen strategy in the direction of reproductive medicine.

\section{References}

1. Lesovska SG (2017) The state of introduction of auxiliary reproductive technologies in Ukraine. The word about health p. 8.

2. Kyiv (2017) The state of health of the female population in Ukraine for 2016 (analytical and statistical guide). DZ "Center of medical statistics of the Ministry of Health of Ukraine".

3. Williamson L, Sangster S, Bayly M, Gibson K, Lawson K, et al. (2017) A needs assessment on addressing environmental health issues within reproductive health service provision: Considerations for continuing education and support. Can Med Educ J 8(4): e65-e73. 
(C) (1) Tomons Attribution 4.0 License

DOI: 10.19080/GJORM.2018.04.555647

\section{Your next submission with Juniper Publishers} will reach you the below assets

- Quality Editorial service

- Swift Peer Review

- Reprints availability

- E-prints Service

- Manuscript Podcast for convenient understanding

- Global attainment for your research

- Manuscript accessibility in different formats ( Pdf, E-pub, Full Text, Audio)

- Unceasing customer service

Track the below URL for one-step submission https://juniperpublishers.com/online-submission.php 